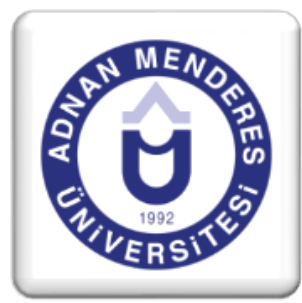

\section{Türk Tekstil ve Hazır Giyim Sektörünün Uluslararası Rekabet Gücü: ASEAN-5 Ülkeleri ile Karşılaştırmalı Analiz}

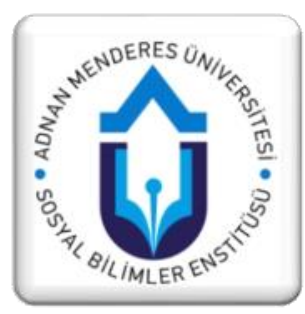

\title{
ÖZET
}

Tekstil ve hazır giyim sektörü ihracat ve istihdam bakımından önemli bir sanayi sektörüdür. Tekstil ve hazır giyim ihracatı son 20 yılda 2 kattan fazla bir artış göstermiştir. Sektör, toplam ihracatın \%19'unu oluşturmaktadır. $\mathrm{Bu}$ çalışmanın ana amacı Türkiye tekstil ve hazır giyim sektörünün ASEAN-5 ülkeleri karşısındaki rekabet gücünü belirlemektir. Bu amaçla Açıklanmış Karşılaştırmalı Üstünlükler, Açıklanmış Simetrik Karşılaştırmalı Üstünlükler ve Ticaret Dengesi İndekslerinden yararlanılmıştır. Çalışma 2000-2014 yıllarını kapsamaktadır. Araștırmada kullanılan veriler BM COMTRADE istatistiki veri tabanından elde edlmiștir. Araștırma sonucunda Türkiye "nin tekstil ve hazır giyim sektöründe ASEAN-5 ülkeleri karşısında güçlü bir rekabet gücüne sahip olduğu tespit edilmiştir. Ancak, son yıllarda indeks değerleri sürekli gerilemektedir. Türkiye'nin tekstil ve hazır giyim ticaretindeki uluslararası rekabet gücünün arttırılması için üretimde kalite ve tasarıma daha fazla önem verilmelidir.

Anahtar Kelimeler: Dış Ticaret, Karşılaştırmalı Üstünlük, Türkiye.

\section{International Competitive Power of Turkish Textile and Apparel Sector: Comparative Analysis with the ASEAN-5 Countries}

\begin{abstract}
Textile and apparel sector is an important industry in terms of export and employment. In the last 20 years, the export of textile and apparel sector has grown more than 2 times. The industry accounts for nearly 19 per cent of total exports. The main aim of this study is to examine the competitive power of Turkish textile and apparel sector against ASEAN-5 countries during the period 2000-2014. In this study, Revealed Comparative Advantage, Revealed Symmetric Comparative Advantage and Trade Balance Indexes are used. The data were obtained from statistical database UN COMTRADE. The analysis shows that Turkey has a strong competitive power in textile and apparel sector against ASEAN-5 countries. But the value of indices is constantly decreasing. To improve the international competitiveness of Turkey in textile and clothing trade should pay attention to the quality and design in production.
\end{abstract}

Key Words: Foreign Trade, Comparative Advantage, Turkey 


\section{Giriş}

Tekstil endüstrisi, pamuk, pamuklu iplik ve dokuma, yün, yünlü iplik ve dokuma, ipek, ipekli dokuma, sentetik iplik, sentetik dokuma, kord bezi, keten, kenevir ve tüm bunların türevlerinden elde edilen ürünlerin kullanıldığı hazır giyim konfeksiyon ile el ve makine halıları alt sektörlerinden meydana gelmektedir (Aruoba, 1999: 31). Tekstil ve hazır giyim sektörünün gelişmesi, Avrupa ve Kuzey Amerika'da ve sanayileşmiş olarak nitelendirilen ülkelerde yapılan suni ve sentetik elyaf üretimi ile başlamış, özellikle II. Dünya Savaşı'nı izleyen süreçte başta Tayvan, Güney Kore, Çin ve Türkiye olmak üzere birçok gelişmekte olan ülkelerde de yaygınlaşmıştır (Çoban ve Kök, 2005: 70). Bugün tekstil ve hazır giyim sekörü dünyanın en eski, en büyük ve en küreselleşmiş endüstrilerden biridir (Keane ve te Velde, 2008: 7).

Tekstil ve hazır giyim sektörü, sağladığı katma değer, istihdam ve ihracat imkânları nedeniyle gelişmekte olan ülkelerin ekonomik kalkınma sürecinde önemli rol oynayan bir sanayi dalıdır (Çetin ve Ecevit, 2008: 117). Günümüzde tekstil ve hazır giyim sektörü hem gelişmiş hem de gelişmekte olan ülke ekonomilerinin önemli bir ayağını oluştururken, aynı zamanda birçok ülkede bütçe gelirlerinin önemli bir kısmını oluşturmaktadır (Azhimetova, 2010: 37). Bununla birlikte tekstil ve hazır giyim sektörü dünya genelinde milyonlarca insana istihdam kaynağı sağlamakta (Tandon ve Reddy, 2013: 81) ve birçok gelişmekte olan ülkelerin önemli bir ihracat kalemini oluşturmaktadır. Tekstil ve hazır giyim sektörü gelişmekte olan ülkelerde sanayi istihdamının \%35'ini ve az gelişmiş ülkelerde ise \%8090'nını oluşturmaktadır. Bununla beraber tekstil ve hazır giyim sektörü birçok gelişmekte olan ülkelerde toplam sanayi ürünleri ihracatının \%50'den fazlasını oluşturmaktadır (Keane ve te Velde, 2008: 11).

Tekstil ve hazır giyim sektörü gerek ihracat ve gerekse istihdam potansiyeli nedeni ile birçok gelişmekte olan ülkelerde ekonominin itici gücü olarak kabul edilmektedir. Günümüzde de bu sanayi dalı sermaye sıkıntısı yaşayan, ucuz işgücüne sahip gelişmekte olan ülkelerin sanayileşme sürecinde önemli rol oynamaktadır. Tekstil ve hazır giyim sektörü, Türkiye ekonomisi açısından da büyük önem taşımaktadır. Tekstil ve hazır giyim sektörü Türkiyede sanayinin lokomotifi konumunda olup, en yüksek istihdam oranı bu sektörde yer almaktadır. $\mathrm{Bu}$ durum bu sektörde rekabetin önemini daha da artırmaktadır. Türkiye, küreselleşen dünyanın gittikçe yoğunlaşan rekabet ortamında başarılı olmak için üretimini, ürün kalitesini ve rekabet gücünü arttırmak zorundadır (Kaya, 2013).

Bu çalışmanın temel amacı Türkiye'nin tekstil ve hazır giyim sektörünün rekabet gücünü belirlemektir. Bu amaçla Türk tekstil ve hazır giyim sektörü ASEAN-5 ülkeleri (Endonezya, Malezya, Tayland, Filipinler ve Singapur) ile karşılaştırmalı olarak analiz edilmiştir. Çalışmada küresel tekstil ve hazır giyim ticaretinin mevcut durumu incelendikten sonra çeşitli indeksler yardımıyla Türk tekstil ve hazır giyim sektörnün rekabet gücü ortaya konmuştur.

Çalışma 7 bölümden oluşmaktadır. Birinci bölüm giriş kısmında oluşmaktadır. Giriş bölümünden takiben 2 . bölümde rekabet gücü kavramı üzerinde durulmuştur. 3. bölümde konu ile ilgili çalışmalar hakkında kısa bilgiler sunulmuştur. Dünya tekstil ve hazır giyim ticaretindeki gelişmeler çalışmanın 4. bölümünde ele alınmıştır. 5. bölümde çalışmada kullanılan veri seti ve metot ile ilgili bilgiler verilmiştir. Çalışmanın 6 . bölümünde araştırma bulgularına yer verilmiştir. Son bölümde ise araştırma sonucunda elde edilen bulgular genel olarak değerlendirilmiş ve bazı önerilerde bulunulmuştur. 


\section{Rekabet Gücü Kavramı}

Küreselleşmeyle birlikte ekonomik sınırların büyük ölçüde ortadan kalktı̆̆ı uluslararası pazarlarda, başarının en önemli koşulu rekabet gücü olmaktadır. Küreselleşen dünyada kalkınma, iç dinamikler kadar dış dinamiklerin de belirlediği bir olgudur. Gelişmiş veya gelişmekte olan ekonomiler için rekabetçi üstünlük yaratmak iktisat ve kalkınma politikalarının önemli bir konusu olarak kalmaya devam etmektedir (Kaya ve Oduncu, 2016: 419).

Literatürde rekabet kavramı ile ilgili çok çeşitli yaklaşımlar bulunmakla birlikte, iktisatçıların üzerinde anlaştıkları tek bir tanım bulunmamaktadır. Rekabet gücü kavramı ele alınan alana (firma, endüstri ve ülke) rekabet gücünü belirlemede kullanılan ölçütlere ve bakış açısına bağlı olarak (mikro veya makro) farklı biçimlerde tanımlanmaktadır (Aktan ve Vural, 2004: 11). Genel olarak rekabet gücü, ülkelerin serbest ve yerleşik pazar koşulları altında vatandaşlarının reel gelirlerini artırmaya çalışırken aynı anda ürettiği ürün ve hizmetleri uluslararası pazarlara sunabilmesi ve bunda başarılı olabilmesidir (Çivi, 2001: 22). Bir başka ifadeye göre rekabet gücü, bir ülkenin ürettiği mallarda diğer ülkelerin malları ile fiyat, kalite, tasarım, güvenilirlik ve zamanında teslim gibi unsurlarda yarışabilir düzeyde olmasıdır (Kelleci, 2009: 11). Rekabet gücü, istihdam olanakları, artan yaşam standardı ve ülkelerin uluslararası yükümlülüklerini yerine getirebilme yeteneğiyle ilgilidir. Rekabet gücünün çok sayıda kaynağı bulunmakla birlikte rekabet gücünün kaynaklarını; teknoloji, beşeri sermaye, örgütsel yapı, sermaye-finansal sektör ve devletin ekonomideki rolü olarak sıralamak mümkündür (Şahin, 2016a: 73).

Rekabet gücü çağımızda uluslar için adeta hayati öneme sahip bulunmaktadır. Geçmişte sadece firma düzeyinde düşünülen bu olgu, son dönemlerde gittikçe yoğunlaşan küreselleşme ve bölgeselleşme eğilimlerinin etkisiyle günümüzde uluslararası düzeyde önem kazanmıştır. Bu rekabet ortamından ülkelerin rekabete açık sektörleri daha yoğun biçimde etkilenmektedir. Bu tür rekabete açık sektörlerden biri de tekstil ve hazır giyim sektörüdür. Tekstil ve hazır giyim sektörü Türkiye'nin geleneksel imalat sanayii içinde önde gelen sektörlerden biridir. Tekstil ve hazır giyim sektörü Türk imalat sanayisi içerisinde en hızlı büyüme artışını yakalayan sektörlerden biridir. Sektör katna değer, istihdam ve ihracat bakımından ülke ekonomisine sağladığı katkılarından ötürü Türk ekonomisi için stratejik bir öneme sahiptir.

Uluslararası rekabetin şekil değiştirdiği günümüzde tekstil ve hazır giyim sektöründe yoğun bir rekabet süreci yaşanmaktadır. Özellikle 2005 yılından itibaren Çok Elyaflılar Anlaşması'nın sona ermesi ile birlikte tekstil ve hazır giyim ticaretinde yeni bir rekabet süreci başlamıştır. Bu süreçte ucuz işgücüne sahip ve nispi olarak düşük maliyetli üretim yaparak ihracatta fiyat avantajı elde eden Çin, Hindistan, Pakistan, Endonezya, Hong Kong, Tayland, Vietnam gibi ülkeler dünya tekstil ve hazır giyim piyasalarında daha fazla söz sahibi olmaya başlamıştır. Söz konusu ülkelerin Türkiye ile ihracat benzerliği düşünüldüğünde, küresel piyasalardaki gelişmelerin Türk tekstil ve hazır giyim ihracat rekabet gücü açısından tehdit unsuru taşıdığı açıktır (Erkan, 2013: 106).

\section{Literatür Araştırması}

Bugüne kadar tekstil ve hazır giyim sektörünün rekabet gücünü ölçmek için ulusal ve uluslararası düzeyde birçok çalışma yapılmıştır. Bu çalışmaların önemli bir kısmı ise Balassa indeksi olarak da bilinen Açıklanmış Karşılaştırmalı Üstünlükler indeksi kullanılarak yapılan 
çalışmalardır (Aynagöz Çakmak, 2005: 66). Bu bölümde söz konusu çalışmaların bazıları hakkında kısa bilgiler sunulmaktadır.

Yean (2001) Malezya'nın imalat sanayi sektörünün rekabet gücü analiz edilmiştir. Çalı̧̧mada Açıklanmış Karşılaştırmalı Üstünlükler indeksi ile Net Ticaret indeksi kullanılmıştır. Araştırma bulgularına göre Malezya gıda, ağaç ürünleri, mobilya ve elektrikli makineler ihracatında rekabet gücüne sahipken, tütün, tekstil ve hazır giyim, deri ve deri ürünleri, ayakkabı, kağıt, petrol ve ptrol ürünleri, kimyasal ürünler plastik, demir ve çelik ihracatında ise rekabet gücüne sahip değildir.

Altay ve Gacaner (2003) Türk tekstil ve hazır giyim sektörünün, Avrupa Birliği (AB) ve Amerika Birleşik Devletleri (ABD) piyasalarında Çin'e karşı rekabet gücünü analiz etmiştir. Araştırmada Balassa'nın Açıklanmış Karşılaştırmalı Üstünlükler indeksi kullanılmıştır. Analiz sonucunda Türkiye'nin söz konusu sektörde hem AB hem de ABD piyasasında rekabet üsütnlüğüne sahip olduğu belirlenmiştir.

Çoban ve Kök (2005) Türk tekstil endüstrisinin $\mathrm{AB}$ ülkeleri karşısındaki rekabet gücü incelenmiştir. Araştırmada Balassa tarafından geliştirilen Açıklanmış Karşılaştırmalı Üstünlükler (AKÜ) indeksi kullanılmıştır. Araştırma sonucunda Türkiye'nin AB ülkeleri karşısında yüksek bir rekabet gücüne sahip olduğu belirlenmiş, ancak Türk tekstil endüstrisinin rekabet gücünde önemli düşüşler olduğu saptanmıştır.

Aydoğuş ve Diler (2009) Türk tekstil sektörünün Çin karşısındaki rekabet gücü analiz edilmiştir. Araştırmada 1996-2007 yılları için Açıklanmış Karşılaştırmalı Üstünlükler katsayısı hesaplanmıştır. Araşırma sonucunda tekstil sektöründe Türkiye'nin rekabet gücünün Çin'e göre yüksek olduğu tespit edilmiştir. Rekabet gücünün devam ettirilebilmesi için sektörde verimlilik, teknolojik gelişme ve AR-GE yatırımlarına önem verilmesi gerektiği vugulanmıştır.

Watchravesringkan vd. (2010) Çalışmada Porter'in Elmas modeli kullanılarak Tayland'ın hazır giyim sektöründeki rekabet gücü değerlendirilmiştir. Araştırma bulgularına göre ulusal pazarda talebin artması, nitelikli iş gücü ve firmaların ihracata önem vermeleri sonucu hazır giyim sektörü rekabetçi konumunu zaman içerisinde güçlendirmiştir. Bununla birlikte, sektörün rekabet gücünün artırılmasında hükümetin önemli rol üstlendiği belirtilmektedir.

Yücel (2010) Türk tekstil ve hazır giyim sektörünün Çin karşısındaki rekabet gücünü ölçmüştür. Araştırmada Balassa indeksi ile birlikte Vollrath tarafından geliştirilen indeksler de kullanılmıştır. Buna göre Türkiye'nin tekstil ve hazır giyim sektöründe rekabet gücne sahip olduğu belirlenmiştir. Ancak, tekstil ve hazır giyim sektöründe Çin'in Türkiye'ye göre daha rekabetçi avantaja sahip olduğu tespit edilmiştir.

Rahmaddi ve Ichihashi (2012) 1987-2008 yılları arasında Endonezya'nın imalata sanayiinin rekabet gücü analiz edilmştir. Araştırmada Pazar Payı ve Açıklanmış Karşılaştırmalı Üstünlükler indeksi kullanılmıştır. Araştırma bulgularına göre, Endonezya kauçuk ve kauçuktan eşya, ahşap eşya, kağıt ve karton, tekstil ve hazır giyim, madenler, mobilya ve ayakkabı ihracatında rekabet gücüne sahiptir.

Altıntaş ve Akpolat (2013) Türkiye'nin tekstil sektöründe AB ülkeleri karşısındaki rekabet gücü analiz edilmiştir. Araştırmada 2004-2011 dönemi verileri kullanılarak Balassa, Vollrath indeksleri ve Karşılaştırmalı İhracat Performansı (KİP) indeksi yardımıyla Türk tekstil sektörünün rekabet düzeyi incelenmiştir. Araştırma sonucunda Türkiye'nin tekstil sektöründe $\mathrm{AB}$ ülkleri karşısında rekabet avantajına sahip olduğu belirlenmiştir. 
Erkan (2013) Araştırmada Balassa, Vollrath ve ihracat-ithalat oranı indeksleri kullanılarak 1993-2009 dönemi için Türkiye'nin tekstil ve hazır giyim sektöründeki rekabet gücü analiz edilmiştir. Analiz sonucuna göre Türkiye tekstil sektörünün alt ürün grubunun 43'ünde ve hazır giyim sektörünün alt ürün grubunun 34'ünde rekabet avantajına sahiptir.

Özçalık ve Okur (2013) Türkiye tekstil ve hazır giyim sektörünün AB ülkeleri karşısında açılanmış karşılaştırmalı üstünlükleri incelenmiştir. Araştırmada Ticarette Uzmanlaşma indeksi ile Net Ticaret indeksi kullanılmıştır. Analiz sonucunda Türkiye'nin AB ülkeleri karşısında rekabetçi avantaja sahip olduğu görülmüsşür. Ancak, son dönemlerde yaşanan ekonomik kriz sonucu Türkiye'nin tekstil ve hazır giyim sektöründe sahip olduğu rekabetçi avantajının gerilediği gözlemlenmiştir.

Şahin (2015) Türkiye'nin tekstil ve hazır giyim sektörünün rekabet gücü Çin ile karşılaştırılmıştır. Rekabet gücü göstergesi olarak, açıklanmış karşılaştırmalı üstünlükler yaklaşımı esas alınmıştır ve SITC Rev.3 iki ve üç haneli ürün grupları açısından hesaplama yapılmıştır. Sonuç olarak Türkiye ve Çin'in tekstil ve hazır giyim sanayinde rekabet gücünün yüksek olduğu görülmüştür. Ancak Türkiye'nin açıklanmış karşıllaştırmalı üstünlük katsayısının Çin'e göre daha yüksek olduğu belirlenmiştir.

Şahin (2016b) 2000-2014 yılları arasında ASEAN-5 ülkelerinin tekstil ve hazır giyim sektöründeki rekabet güçleri incelenmiştir. Çalışmada Pazar Payı indeksi, Ticarette Uzmanlaşma indeksi ve Açıklanmış Karşılaştırmalı Üstünlükler indeksi kullanılmıştır. Elde edilen bulgulara göre, Endonezya tekstil ve hazır giyim sektöründe rekabet avantajına sahipken, Filipinler hazır giyim sektöründe rekabet avantajına sahiptir. Diğer ülkeler ise ele alınan sektörlerde rekabet dezavantajına sahiptir.

\section{Dünyada Tekstil ve Hazır Giyim Sektörü}

Tekstil ve hazır giyim sektörü uzun zamandan beri uluslararası ticarette önemli bir yer tutmaktadır. Dünya tekstil ve hazır giyim ihracatı 1990 yılında 210 milyar dolar iken, 2014 yılında 797 milyar dolara ulaşmıştır. 2014 yılı itibariyle sektörün dünya toplam mal ticaretindeki payı ise \%4,3'dür (DTÖ, 2016). Son yirmi yılda tekstil ve hazır giyim ticareti hızlı bir büyüme kaydetmiştir. 1990'lı yıllarda piyasanın yıllık büyüme hızı yaklaşık \%5 iken, günümüzde bu oran \%10'un üzerinde seyretmektedir (Corovic vd., 2013: 9).

Son otuz y1lda küreselleşmenin etkisiyle birlikte dünya tekstil ve hazır giyim ticaretinde önemli değişimler yaşanmaktadır. 1980'li yıllardan itibaren hız kazanan küreselleşme eğilimi dünya tekstil ve hazır giyim sanayinde ticaret akışını hızlandırmış son otuz yıl içerisinde yaklaşık olarak sektörün toplam kapasitesinin yarısı gelişmiş ülkelerden gelişmekte olan ülkelere doğru kaymıştır (Eraslan vd., 2008: 266). Gelişmekte olan ülkeler son yirmi yıl içerisinde tekstil piyasasındaki pazar paylarını önemli ölçüde arttırmışlardır. Tekstil ve hazır giyim ürünleri ticaretinde önde gelen ülkeler arasında Çin, $\mathrm{AB}$, Hindistan, Türkiye, Bangladeş, Vietnam ve Pakistan gibi ülkeler yer almaktadır. ABD, Japonya ve Güney Kore'nin dünya tekstil ve hazır giyim ticaretindeki payları ise giderek azalmaktadır (Fukunishi vd., 2013). Bununla beraber ABD ve AB ülkeleri gibi gelişmiş sanayi ülkeleri hala güçlü ihracatçı ülkelerdir.

Dünya Ticaret Merkezi’nin verilerine göre Çin dünyanın en büyük tekstil ve hazır giyim ürünleri üreticisi ve aynı zamanda en büyük ihracatçısıdır. Son yirmi yılda Çin'in dünya tekstil ve hazır giyim ticaretindeki payı \%10'dan \%30'lara kadar yükselmiştir (You vd., 2009: 33). 2014 yılında Çin'in toplam tekstil ve hazır giyim ihracatı bir önceki yıla göre \%5 artış göstererek 298 milyar dolara ulaşmış ve dünya tekstil ve hazır giyim ihracatındaki payı 
ise \%37,4 olarak gerçekleşmiştir (DTÖ, 2016). AB, toplam 200 milyar dolar ihracatı ile dünya tekstil ve hazır giyim ihracatında ikinci sırada yer almaktadır. Ancak bunun yarısından fazlası birlik içi ticaretten oluşmaktadır. İtalya, Almanya, Fransa, İspanya ve İngiltere Avrupa tekstil ve hazır giyim ticaretinde önemli paya sahip olan ülkelerdir. Son yıllarda AB'nin dünya tekstil ve hazır giyim ihracatındaki payı sürekli azalmaktadır. Bununla birlikte gelişmiş bazı $\mathrm{AB}$ ülkeleri, gelişmiş teknoloji üstünlüklerini de kullanarak yeni rekabet ortamında öne çıkma çabası içindedirler. Modaya bağlı, üretimleri özel know-how gerektiren, yüksek kaliteli ve katma değeri yüksek ürünlerin yanı sıra akıllı tekstiller ve teknik tekstiller üretimine ağırlık vermeye başlamışlardır (Arslan, 2008: 119).

Tablo 1'de dünya tekstil ve hazır giyim ticaretinde önde gelen ülkelerin ihracat değerleri ile ihracattaki paylarına ilişkin veriler sunulmaktadır. 2000-2014 döneminde Avrupa Birliği (AB) ülkelerinin tekstil ve hazır giyim ihracatındaki payı 2000 yılından bugüne kadar sürekli gerileyerek 2014 yılında \%6,90 olarak gerçekleşmiştir. Aynı dönemde Çin'in ihracattaki pay1 ise sürekli artarak 2014 yılında \%37'ye ulaşmıştır. ABD, Hong Kong ve Güney Kore'nin ihracattaki payları incelenen dönemde sürekli gerilemektedir. Buna karşın Hindistan ve Türkiye'nin ihracattaki payları ise sürekli artmaktadır. Sonuç olarak 2000-2014 yılları arasında dünya tekstil ve hazır giyim ihracatında gelişmiş ülkelerin payı azalırken, gelişmekte olan ülkelerin payı ise artmıştır.

Tablo 1. Dünya Tekstil ve Hazır Giyim İhracatında Önde Gelen Ülkeler

\begin{tabular}{|l|c|c|c|c|c|c|}
\hline \multirow{2}{*}{ Ülkeler } & \multicolumn{2}{|c|}{$\mathbf{2 0 0 0}$} & \multicolumn{2}{c|}{$\mathbf{2 0 1 0}$} & \multicolumn{2}{c|}{$\mathbf{2 0 1 4}$} \\
\cline { 2 - 7 } & $\begin{array}{c}\text { İhracat } \\
\text { (Milyar \$) }\end{array}$ & $\begin{array}{c}\text { Oran } \\
(\boldsymbol{\%})\end{array}$ & $\begin{array}{c}\text { İhracat } \\
\text { (Milyar \$) }\end{array}$ & $\begin{array}{c}\text { Oran } \\
(\boldsymbol{\%})\end{array}$ & $\begin{array}{c}\text { İhracat } \\
\text { (Milyar \$) }\end{array}$ & $\begin{array}{c}\text { Oran } \\
(\boldsymbol{\%})\end{array}$ \\
\hline Çin & 52 & 14,77 & 206 & 34,05 & 298 & 37,39 \\
\hline AB-28 & 28 & 7,95 & 43 & 7,11 & 55 & 6,90 \\
\hline Hindistan & 11 & 3,13 & 24 & 3,97 & 36 & 4,52 \\
\hline Hong Kong & 37 & 10,51 & 35 & 5,79 & 30 & 3,76 \\
\hline Türkiye & 10 & 2,84 & 24 & 3,97 & 29 & 3,64 \\
\hline ABD & 11 & 3,13 & 16 & 2,64 & 20 & 2,51 \\
\hline Güney Kore & 17 & 4,83 & 12 & 1,98 & 14 & 1,76 \\
\hline Dünya & $\mathbf{3 5 2}$ & $\mathbf{1 0 0 , 0 0}$ & $\mathbf{6 0 5}$ & $\mathbf{1 0 0 , 0 0}$ & $\mathbf{7 9 7}$ & $\mathbf{1 0 0 , 0 0}$ \\
\hline
\end{tabular}

Kaynak: DTÖ, 2016.

Not: "a" Birlik dişı

Dünya tekstil ve hazır giyim ürünleri ithalatı da her geçen gün artmaktadır. Bunda en büyük etken, dünya nüfusundaki hızlı artış ve tekstil ve hazır giyim tüketiminde modanın belirleyici rolünün artmış olmasıdır. Dünya tekstil ve hazır giyim ithalatında Amerika Birleşik Devletleri ve Avrupa Birliği ülkeleri ilk sıralarda yer almaktadır. Günümüzde dünya tekstil ve hazır giyim ithalatında $A B$ ülkeleri ilk sırada gelmektedir. 2014 y1lı itibariyle $A B$ ülkelerinin dünya tekstil ve hazır giyim ürünleri ithalatından aldığ sirasiyla ABD $(\% 17,54)$, Japonya $(\% 5,80)$, Çin $(\% 3,77)$, Hong Kong $(\% 3,62)$, Kanada $(\% 2,17)$ ve Güney Kore $(\% 1,88)$ takip etmektedir. Dünya tekstil ve hazır giyim ithalatında önde gelen ülkeler ile ilgili bilgiler Tablo 2'de sunulmaktadır. 
Tablo 2. Dünya Tekstil ve Hazır Giyim İthalatında Önde Gelen Ülkeler

\begin{tabular}{|c|c|c|c|c|c|c|}
\hline \multirow[t]{2}{*}{ Ülkeler } & \multicolumn{2}{|c|}{2000} & \multicolumn{2}{|c|}{2010} & \multicolumn{2}{|c|}{2014} \\
\hline & $\begin{array}{c}\text { Itthalat } \\
\text { (Milyar \$) }\end{array}$ & $\begin{array}{c}\text { Oran } \\
(\%)\end{array}$ & $\begin{array}{c}\text { Itthalat } \\
\text { (Milyar \$) }\end{array}$ & $\begin{array}{c}\text { Oran } \\
(\%)\end{array}$ & $\begin{array}{c}\text { İthalat } \\
\text { (Milyar \$) }\end{array}$ & $\begin{array}{c}\text { Oran } \\
(\%)\end{array}$ \\
\hline AB-28 ${ }^{\mathrm{a}}$ & 55 & 15,11 & 115 & 19,73 & 136 & 19,71 \\
\hline $\mathrm{ABD}$ & 83 & 22,80 & 105 & 18,01 & 121 & 17,54 \\
\hline Japonya & 24 & 6,59 & 34 & 5,83 & 40 & 5,80 \\
\hline Çin & 13 & 3,57 & 21 & 3,60 & 26 & 3,77 \\
\hline Hong Kong & 29 & 7,97 & 28 & 4,80 & 25 & 3,62 \\
\hline Kanada & 8 & 2,20 & 12 & 2,06 & 15 & 2,17 \\
\hline Güney Kore & 4 & 1,10 & 9 & 1,54 & 13 & 1,88 \\
\hline Türkiye & 2 & 0,55 & 9 & 1,54 & 10 & 1,45 \\
\hline Dünya & 364 & 100,00 & 583 & 100,00 & 690 & 100,00 \\
\hline
\end{tabular}

Kaynak: DTÖ, 2016.

Not: "a" Birlik dış1

\section{Materyal ve Yöntem}

$\mathrm{Bu}$ çalışmada kullanılan veriler ve bilgiler ikincil kaynaklardan elde edilmiştir. Çalışmada Standart Uluslararası Ticaret Sınıflandırması (SITC Rev.3) dikkate alınmıştır. SITC Rev.3 iki haneli ürün sınıflandırmasına göre tekstil ve hazır giyim ürünlerine ait fasıllar sırasıyla SITC 65 ve SITC 84'dür. Araştırmada kullanılan veriler dolar bazında olup Birleşmiş Milletler COMTRADE veri tabanından derlenmiştir. Araştırmada kullanılan veriler 2000, 2005, 2010 ve 2014 y1llarına aittir.

Türk tekstil ve hazır giyim sektörünün rekabet gücünü belirleyebilmek için Açıklanmış Karşılaştırmalı Üstünlükler (AKÜ) indeksi, Açıklanmış Simetrik Karşılaştırmalı Üstünlükler (ASKÜ) indeksi ve Ticaret Dengesi indeksinden (TBI) yararlanılmıştır. Açıklanmış Karşılaştırmalı Üstünlükler (AKÜ) indeksi Bela Balassa tarafından geliştirilmiştir. Açıklanmış Karşılaştırmalı Üstünlükler kavramı, belli bir malın ihracatında, bir ülkenin gösterdiği performansın, bu malın "dünya" ihracatındaki performansıyla karşılaştırılmasına dayanır. Eğer ülkenin performansı, "dünya"nın performansından daha iyi ise, o ülkenin söz konusu malda karşılaştırmalı üstünlüğe sahip olduğu sonucuna varılır (Erlat ve Erlat, 2004: 49). AKÜ indeksi, ülkelerin güçlü ve zayıf ihracatçı sektörlerini belirlemeye yönelik ampirik çalışmalarda kullanılmaktadır (Hinloopen ve Marrewijk, 2004: 1). AKÜ yaklaşımında ticaret sonrası verilere dayalı olarak ölçüm yapılmakta ve uluslararası ticaretin ürün bileşiminin ülkeler arasındaki göreli maliyetler kadar fiyat dışı faktörleri de yansıttığı varsayılmaktadır. $\mathrm{Bu}$ varsayım, ticareti yapan ülkeler arasındaki karşılaştırmalı üstünlükleri 'açıklamak' amacı ile yapılmaktadır (Eroğlu ve Özdamar, 2006: 96-97). AKÜ indeksi aşağıdaki şekilde formüle edilmektedir:

$$
\operatorname{AKU}_{\mathrm{ij}}=\left(\frac{\mathrm{x}_{\mathrm{ij}}}{\mathrm{x}_{\mathrm{i}}}\right) /\left(\frac{\mathrm{x}_{\mathrm{jw}}}{\mathrm{x}_{\mathrm{w}}}\right)
$$

Formül 1'de, AKÜ $\ddot{i j}_{\mathrm{ij}}$ ' 'i' ülkesinin 'j' sektörü için açıklanmış karş1laştırmalı üstünlükler indeksini, $X_{i j}$ ' $i$ ' ülkesinin ' $j$ ' sektörünün ihracatını, $X_{i}$ 'i' ülkesinin toplam ihracatını, $X_{w j}$ 'j' sektörü dünya ihracatını ve $X_{w}$ toplam dünya ihracatını göstermektedir. AKÜ indeksi 0 ile $\infty$ arasında bir değer almaktadır. Eğer indeks değeri birden büyükse o ülkenin ilgili sektörde karşılaştırmalı üstünlüğe sahip olduğu söylenir. Başka bir deyişle, o endüstrinin ülkenin toplam ihracatı içindeki payı, dünya ticaretindeki payından daha büyüktür. Eğer indeks değeri birden az ise ülkenin ilgili sektörde karşılaştırmalı dezavantaja sahip olduğu söylenir (Havrila and Gunawardana, 2003: 108; Aynagöz Çakmak, 2005: 70). Bununla beraber, eğer 
AKÜ $>4$ ise güçlü bir karşılaştırmalı üstünlük; $2<\mathrm{AKÜ}<4$ orta derecede karș1laștırmalı üstünlük; $1<\mathrm{AKÜ}<2$ zayıf bir karşılaştırmalı üstünlük; $0<\mathrm{AKÜ}<1$ ise karşılaştırmalı dezavantaj söz konusudur (Hinloopen ve Marrewijk, 2001: 13).

Balassa'nın AKÜ indeksi bazı sorunlar içermesine rağmen, ampirik çalışmalarda en çok kullanılan yöntemlerden biridir (Fertö, 2007: 8). Zamanla Balassa'nın AKÜ indeksine alternatif olarak birçok yeni indeksler geliştirilmiştir. Bunlardan biri de Açıklanmış Simetrik Karşılaştırmalı Üstünlükler (ASKÜ) indeksidir. $\mathrm{Bu}$ indeks aşağıdaki şekilde formüle edilmektedir:

$$
\mathrm{ASKU}_{\mathrm{ij}}=\left(\mathrm{AKU}_{\mathrm{ij}}-1\right) /\left(\mathrm{AKU} \ddot{\mathrm{ij}}_{\mathrm{j}}+1\right)
$$

ASKÜ indeksi -1 ile +1 arasında bir değer almaktadır. Eğer indeks değeri pozitif ise ulke o üründe karşılaştırmalı üstünlüğe sahiptir. Eğer indeks değeri negatif ise ülke o ürünün ticaretinde karşılaştırmalı dezavantaja sahiptir (Dalum ve ark., 1998; Laursen, 1998: 2).

Araştırmada kullanılan bir diğer ölçüt de Ticaret Dengesi İndeksidir (TBI). Lafay (1992) tarafindan geliştirilen bu indeks bir ülkenin ilgili üründe net ihracatçı veya net ithalatçı olup olmadığını belirlemek için kullanılmaktadır (Widodo, 2008: 159; Ishchukova ve Smutka, 2013: 16). İndeks şu şekilde formüle edilmektedir:

$$
\mathrm{TBI}_{\mathrm{ij}}=\left(\mathrm{X}_{\mathrm{ij}}-\mathrm{M}_{\mathrm{ij}}\right) /\left(\mathrm{X}_{\mathrm{ij}}+\mathrm{M}_{\mathrm{ij}}\right)
$$

Formül 3'de i ülkeyi, j ürünü, $X$ ihracat1, $M$ ithalatı göstermektedir. TBI indeksi -1 ile +1 arasında bir değer almaktadır. Eğer indeks değeri +1 ise ülkenin net ihracatçı konumda olduğu söylenir. Buna karşın eğer indeks değeri -1 ise ülkenin net ithalatçı konumda olduğu söylenir. Eğer indeks değeri 0 ise ülkenin ihracat ve ithalat değerlerinin birbirine eşit olduğu söylenir (Ma, 2013: 138; Altay Topçu ve Sümerli Sarıül, 2015: 336).

Açıklanmış Simetrik Karşılaştırmalı Üstünlükler indeksi ve Ticaret Dengesi indeksi kullanılarak ürün haritası oluşturulmaktadır. Üretim haritası A, B, C, D olarak dört gruptan oluşmaktadır. Bu gruplar şu şekilde açıklanabilir (Widodo, 2008: 160):

\begin{tabular}{|c|c|c|c|c|}
\hline \multirow{2}{*}{$\begin{array}{l}\text { Açıllanmış } \\
\text { Karşılaştırmalı } \\
\text { Üstünlükler } \\
\text { (RSCA) }\end{array}$} & \multirow{2}{*}{$\begin{array}{l}\text { Simetrik } \\
\text { İndeksi }\end{array}$} & $\mathrm{RSCA}>0$ & $\begin{array}{c}\text { Grup B: } \\
\text { Karş1laştırmalı Üstünlük-Net } \\
\text { İthalatçı } \\
(\text { RSCA>0 ve TBI<0) }\end{array}$ & $\begin{array}{c}\text { Grup A: } \\
\text { Karşılaş̧tırmalı Üstünlük-Net } \\
\text { İhracatçı } \\
\text { (RSCA>0 ve TBI>0) }\end{array}$ \\
\hline & & $\mathrm{RSCA}<0$ & $\begin{array}{c}\text { Grup D: } \\
\text { Karşılaştırmalı Dezavantaj- } \\
\text { Net İthalatçı } \\
(\text { RSCA<0 ve TBI<0) }\end{array}$ & $\begin{array}{c}\text { Grup C: } \\
\text { Karşılaştırmalı Dezavantaj-Net } \\
\text { İhracatçı } \\
(\text { RSCA }<0 \text { ve TBI }>0)\end{array}$ \\
\hline & & & $\mathrm{TBI}<0$ & $\mathrm{TBI}>0$ \\
\hline & & & Ticaret Den & i İndeksi (TBI) \\
\hline
\end{tabular}

Tablo 3. Ürün Haritas1 


\section{Araștırma Bulguları}

Tablo 4'de tekstil ve hazır giyim sektöründe ele alınan ülkeler için Açıklanmış Karşılaştırmalı Üstünlükler (AKÜ) indeks değerleri yer almaktadır. Ele alınan ülkeler arasında Türkiye, Endonezya ve Tayland tekstil sektöründe rekabet gücüne sahipken, Malezya, Filipinler ve Singapur ise söz konusu sektörde rekabet gücüne sahip değildir. Yine Türkiye, Endonezya ve Filipinler hazır giyim sektöründe rekabet gücüne sahipken, Malezya, Tayland ve Singapur rekabet gücüne sahip değildir. Tablo 4'den de görüleceği gibi ele alınan sektörlerde Türkiye'nin AKÜ indeks değerleri diğer ülkelere göre oldukça yüksek seviyededir. Hesaplanan AKÜ katsayısına göre Türkiye diğer ülkelere göre tekstil ve hazır giyim sektöründe güçlü bir karşılaştırmalı üstünlüğe (AKÜ>4) sahiptir. Araştırma bulgularına göre tekstil ve hazır giyim sektöründe ele alınan ülkelerin rekabet güçleri giderek zayıflamaktadır. Örneğin, 2000-2014 yılları arasında Türkiye'nin tekstil sektörüne ait AKÜ indeks değeri 5,30'dan 4,91'e ve hazır giyim sektörüne ait AKÜ indeks değeri 7,28'den 4,17'ye gerilemiştir. Tayland ise 2000-2014 yılları arasında hazır giyim sektöründe avantajlı ülke konumundan dezavantajlı ülke konumuna düşmüştür.

Tablo 4. Tekstil ve Hazır Giyim Sektöründe AKÜ İndeks Değerleri

\begin{tabular}{|l|c|c|c|c|c|c|c|}
\hline Yıllar & Sektör & Türkiye & Endonezya & Malezya & Tayland & Filipinler & Singapur \\
\hline \multirow{2}{*}{2000} & Tekstil & 5,30 & 2,54 & 0,56 & 1,25 & 0,28 & 0,30 \\
\cline { 2 - 7 } & Hazır giyim & 7,28 & 2,66 & 0,80 & 1,91 & 2,77 & 0,47 \\
\hline \multirow{2}{*}{2005} & Tekstil & 4,88 & 1,97 & 0,47 & 1,26 & 0,25 & 0,20 \\
\cline { 2 - 7 } & Hazır giyim & 6,00 & 2,14 & 0,63 & 1,39 & 1,99 & 0,28 \\
\hline \multirow{2}{*}{2010} & Tekstil & 4,67 & 1,55 & 0,48 & 1,13 & 0,23 & 0,14 \\
\cline { 2 - 8 } & Hazır giyim & 4,76 & 1,84 & 0,84 & 0,94 & 1,41 & 0,12 \\
\hline \multirow{2}{*}{2014} & Tekstil & 4,91 & 1,59 & 0,46 & 1,02 & 0,19 & 0,12 \\
\cline { 2 - 7 } & Hazır giyim & 4,17 & 1,69 & 0,78 & 0,70 & 1,13 & 0,12 \\
\hline
\end{tabular}

Kaynak: UN Comtrade verileri kullanılarak yazar tarafindan hesaplanmıştır.

Tekstil ve hazır giyim sektöründe ele alınan ülkeler için hesaplanan Açıklanmış Simetrik Karşılaştırmalı Üstünlükle indeks değerleri Tablo 5'de sunulmaktadır. Buna göre tekstil sektöründe karşılaştırmalı üstünlüğe sahip olan ülkeler arasında Türkiye, Endonezya ve Tayland yer almaktadır. Hazır giyim sektöründe karşılaştırmalı üstünlüğe sahip ülkeler ise Türkiye, Endonezya ve Filipinler'dir. Tablo 5'den de görüleceği gibi ele alınan sektörlerde Türkiye'nin ASKÜ indeks değerleri diğer ülkelere göre oldukça yüksek seviyededir.

Tablo 5. Tekstil ve Hazır Giyim Sektöründe ASKÜ İndeks Değerleri

\begin{tabular}{|l|c|c|c|c|c|c|c|}
\hline Yıllar & Sektör & Türkiye & Endonezya & Malezya & Tayland & Filipinler & Singapur \\
\hline \multirow{2}{*}{2000} & Tekstil & 0,68 & 0,43 & $-0,28$ & 0,11 & $-0,56$ & $-0,54$ \\
\cline { 2 - 7 } & Hazır giyim & 0,76 & 0,45 & $-0,11$ & 0,31 & 0,47 & $-0,36$ \\
\hline \multirow{2}{*}{2005} & Tekstil & 0,66 & 0,33 & $-0,36$ & 0,11 & $-0,60$ & $-0,67$ \\
\cline { 2 - 7 } & Hazır giyim & 0,71 & 0,36 & $-0,22$ & 0,16 & 0,33 & $-0,57$ \\
\hline \multirow{2}{*}{2010} & Tekstil & 0,65 & 0,22 & $-0,35$ & 0,06 & $-0,62$ & $-0,76$ \\
\cline { 2 - 8 } & Hazır giyim & 0,65 & 0,30 & $-0,09$ & $-0,03$ & 0,17 & $-0,78$ \\
\hline & Tekstil & 0,66 & 0,23 & $-0,37$ & 0,01 & $-0,68$ & $-0,79$ \\
\cline { 2 - 8 } & Hazır giyim & 0,61 & 0,26 & $-0,13$ & $-0,18$ & 0,06 & $-0,78$ \\
\hline
\end{tabular}

Kaynak: UN Comtrade verileri kullanılarak yazar tarafindan hesaplanmıştır.

Tablo 6'da Ticaret Dengesi İndeksine göre ele alınan ülkelerin tekstil ve hazır giyim sektöründeki rekabet gücü değerleri sunulmaktadır. Buna göre, ele alınan ülkelerin tamamı 
tekstil sektöründe net ithalatçı ülke konumundadırlar. Hazır giyim sektöründe ise Türkiye, Endonezya, Malezya, Tayland ve Filipinler net ihracatçı ülke konumunda iken, Singapur net ithalatçı ülke konumundadır. Ele alınan ülkelere ait Ticaret Dengesi İndeks değerleri incelendiğinde özellikle hazır giyim sektörüne ait indeks değerlerinde bir azalma göze çarpmaktadır. Örneğin, 2000-2014 yılları arasında Türkiye'nin hazır giyim sektörüne ait TBI indeks değeri 0,92 'den 0,68 'e gerilemiştir. Aynı dönemde Endonezya'nın hazır giyim sektörüne ait TBI indeks değeri 0,98'den 0,87'ye, Malezya'nın 0,88'den 0,65'e ve Tayland'in 0,93'den 0,67'ye gerilemiştir. Bu durum incelenen dönemde söz konusu ülkelerde hazır giyim ithalatının çok hızlı bir şekilde arttığını göstermektedir.

Tablo 6. Tekstil ve Hazır Giyim Sektöründe Ticaret Dengesi İndeks Değerleri

\begin{tabular}{|l|c|c|c|c|c|c|c|}
\hline Yıllar & Sektör & Türkiye & Endonezya & Malezya & Tayland & Filipinler & Singapur \\
\hline \multirow{2}{*}{2000} & Tekstil & 0,28 & 0,49 & 0,04 & 0,09 & $-0,71$ & $-0,14$ \\
\cline { 2 - 8 } & Hazır giyim & 0,92 & 0,98 & 0,88 & 0,93 & 0,99 & $-0,03$ \\
\hline \multirow{2}{*}{2005} & Tekstil & 0,23 & 0,63 & 0,14 & 0,17 & $-0,67$ & $-0,05$ \\
\cline { 2 - 8 } & Hazır giyim & 0,89 & 1,00 & 0,79 & 0,91 & 1,00 & $-0,11$ \\
\hline \multirow{2}{*}{2010} & Tekstil & 0,16 & $-0,01$ & 0,14 & 0,17 & $-0,50$ & $-0,11$ \\
\cline { 2 - 8 } & Hazır giyim & 0,64 & 0,99 & 0,81 & 0,80 & 0,99 & $-0,31$ \\
& Tekstil & 0,29 & $-0,10$ & 0,13 & 0,13 & $-0,60$ & $-0,11$ \\
\cline { 2 - 8 } & Hazır giyim & 0,68 & 0,87 & 0,65 & 0,67 & 0,99 & $-0,32$ \\
\hline
\end{tabular}

Kaynak: UN Comtrade verileri kullanılarak yazar tarafından hesaplanmıştır.

Tablo 7'de ele alınan ülkelerin tekstil ve hazır giyim sektörünün ürün haritası yer almaktadır. Araştırma bulgularına göre Türkiye tekstil ve hazır giyim sektöründe A grubunda yer almaktadır. Yani incelenen yıllarda Türkiye tekstil ve hazır giyim sektöründe karşılaştırmalı üstünlüğe sahiptir ve söz konusu sektörde net ihracatçı ülke konumundadır. Endonezya 2000 ve 2005 yıllarında tekstil sektöründe A Grubunda yer alırken, 2010 ve 2014 yıllarında B Grubunda yer almıştır. Buna karşın hazır giyim sektöründe A Grubunda yer almıştır. Malezya incelenen yıllarda tekstil ve hazır giyim sektöründe C Grubunda yer almıştır. Tayland tekstil sektöründe A Grubunda yer almıştır. Hazır giyim sektöründe ise 2000 ve 2005 y1llarında A Grubunda yer alırken, 2010 ve 2014 yıllarında C Grubunda yer almıştır. Filipinler tekstil sektöründe D Grubunda yer alırken, hazır giyim sektöründe A Grubunda yer almıştır. Singapur ise incelenen yıllarda tekstil ve hazır giyim sektöründe D Grubunda yer almıştır.

Tablo 7. Tekstil ve Hazır Giyim Sektörüne Ait Ürün Haritası

\begin{tabular}{|l|c|c|c|c|c|c|c|}
\hline Yıllar & Sektör & Türkiye & Endonezya & Malezya & Tayland & Filipinler & Singapur \\
\hline \multirow{2}{*}{2000} & Tekstil & A & A & C & A & D & D \\
\cline { 2 - 8 } & Hazır giyim & A & A & C & A & A & D \\
\hline \multirow{2}{*}{2005} & Tekstil & A & A & C & A & D & D \\
\cline { 2 - 8 } & Hazır giyim & A & A & C & A & A & D \\
\hline \multirow{2}{*}{2010} & Tekstil & A & B & C & A & D & D \\
\cline { 2 - 8 } & Hazır giyim & A & A & C & C & A & D \\
\hline \multirow{2}{*}{2014} & Tekstil & A & B & C & A & D & D \\
\cline { 2 - 8 } & Hazır giyim & A & A & C & C & A & D \\
\hline
\end{tabular}

Kaynak: Yazar tarafindan oluşturulmuştur.

Not: Ürün Haritası: Grup A: Karşılaştırmalı Üstünlük-Net İhracatçı, Grup B: Karşılaştırmalı Üstünlük-Net İthalatçı, Grup C: Karşılaştırmalı Dezavantaj-Net İhracatçı, Grup D: Karşılaştırmalı Dezavantaj-Net İthalatçı. 
Araştırma bulguları genel olarak değerlendirildiğinde Türkiye'nin tekstil ve hazır giyim sektöründe ASEAN-5 ülkeleri karşısında daha güçlü bir rekabetçi yapıya sahip olduğu görülmektedir. Ancak, artan küresel rekabet karşısında Türkiye'nin tekstil ve hazır giyim sektöründeki rekabet gücünün zamanla zayıfladığı saptanmıştır. ASEAN-5 ülkelerinden ise Endonezya'nın tekstil ve hazır giyim sektöründe rekabet gücüne sahip olduğu, Tayland'ın tekstil sektöründe ve Filipinler'in hazır giyim sektöründe rekabet gücüne sahip olduğu saptanmıştır. Buna karşın Malezya ve Singapur'un tekstil ve hazır giyim sektöründe rekabet gücüne sahip olmadığı belirlenmiştir.

Araştırma sonuçları daha önce yapılan çalışmalar ile uyumluluk göstermektedir. Örneğin, James (2004) tarafından yapılan bir araştırmada Tayland ve Endonezya'nın 1985-2001 yılları arasında tekstil ve hazır giyim sektöründe rekabet gücüne sahip olduğu belirlenmiştir. Rahmaddi ve Ichihashi (2012) tarafından yapılan bir araştırmada Endonezya'nın 1990-2008 yılları arasında tekstil ve hazır giyim sektöründe rekabet gücüne sahip olduğu belirlenmiştir. Erkan (2013) tarafından yapılan araştırmada Türkiye'nin tekstil ve hazır giyim sektöründe rekabet gücüne sahip olduğu belirlenmiştir. Ancak Türkiye'nin söz konusu sektördeki rekabet gücünün zamanla azaldığı saptanmıştır. Şahin (2016b) tarafindan ASEAN-5 ülkelerinin tekstil ve hazır giyim sektöründeki rekabet gücünün incelendiği araştırmada Endonezya'nın her iki sektörde de rekabet gücüne sahip olduğu belirlenirken, Filipinler'in hazır giyim sektöründe rekabet gücüne sahip olduğu saptanmıştır. Buna karşın Tayland, Malezya ve Singapur'un tekstil ve hazır giyim sektöründe rekabet gücüne sahip olmadıkları belirlenmiştir.

Son 20-25 yılda Türk tekstil ve hazır giyim sektörü büyük başarı göstermiş olsa da günümüzde bazı önemli sorunlarla karşı karşıya kalmaktadır. Üretim maliyetlerinin yüksek olması, üretimin ağırlıklı olarak küçük ölçekli işletmelerde yapılması, markalaşma eksikliği, AR-GE faaliyetlerinin yetersizliği ve sektörde kayıt dışı oranının yüksek olması karşılaşılan sorunların başında gelmektedir. Bilindiği gibi tekstil ve hazır giyim sektörünün temel hammaddesini pamuk oluşturmaktadır. Sektörün ihtiyaç duyduğu pamuk iç ve dış piyasalardan temin edilmektedir. Türkiye uygun pamuk arzına sahip olduğu halde rekabet edilebilir fiyatlarla pamuk elde etmek mümkün olamamaktadır. Bu nedenle zaman zaman pamuk ithalatı ülke üretiminin üzerine çıkmıştır. Pamuğun dış piyasalarda Türkiye'den daha ucuz olması özellikle ihracatta rekabeti sürekli zayıflatan bir unsur olarak öne çıkmaktadır. Türk tekstil ve hazır giyim sektöründe üretim maliyetini etkileyen bir diğer faktör de enerjidir. Türkiye'nin enerji bakımından ithalata bağımlı olması ve enerji fiyatlarındaki artışlar maliyetleri yükseltmektedir. Bu durum tekstil ve hazır giyim sektöründeki fiyat rekabeti avantajını ülke aleyhine çevirmektedir. Artan uluslararası rekabet karşısında üretim maliyetlerinin minimize edilmesi büyük önem taşımaktadır. Ancak, tekstil ve hazır giyim sanayinin ucuz işgücü avantajından yararlanacağı dönemler geride kalmaktadır. Günümüzde yeni ürünlerin geliştirilmesi, tasarım, ürün ve hizmet kalitesi, müşteri isteklerine göre ürün ve hizmet üretimi, pazardaki ürünün yaşam süresi gibi pek çok faktör artık maliyetlerden çok daha önemlidir (Can, 2009: 58). Rekabet koşullarının yoğunlaştığı günümüzde dünya pazarlarında rekabet edebilmek için sadece ucuz ürün piyasaya sürmek yeterli olmayıp, kaliteli ürünlere yönlenilmeli ve kalitenin sürekliliği sağlanmalıdır. Bu süreçte özellikle ARGE, inovasyon ve markalaşma gibi daha ileri rekabet unsurları üzerine yoğunlaşmak gerekmektedir. 


\section{Sonuç ve Değerlendirme}

Tekstil ve hazır giyim sektörü, özellikle son 10 yıldaki ihracat potansiyeli, üretim teknolojisi, artan ihraç imkânları ve ihracatçı firma sayısı ile her geçen gün gelişmekte ve Türkiye'nin uluslararası alanda rekabete girdiği ve marka oluşturduğu bir sektör olma yolunda ilerlemektedir. Son yıllarda Türkiye'nin tekstil ve hazır giyim ihracatı hızlı bir gelişme göstermiş ve sektörde markalaşma ve dışa açılma başarısı görülmüştür. Rekabetin yoğun olarak yaşandığı günümüz dünyasında rekabet gücünün artırılması Avrupa Birliği'ne giriş sürecinde olan Türkiye için çok daha farklı bir boyut kazanmıştır. Türkiye'nin küresel pazarlarda yer alabilmesi, herşeyden önce dış pazarlarla rekabet edebilmesine bağlıdır.

Çalışmada Türkiye'nin tekstil ve hazır giyim sektöründeki rekabet gücü Açıklanmış Karşılaştırmalı Üstünlükler İndeksi, Açıklanmış Simetrik Karşılaştırmalı Üstünlükler İndeksi ve Ticaret Dengesi İndeksi kullanılarak analiz edilmiştir. Hesaplanan AKÜ indeks değerlerine göre Türkiye tekstil ve hazır giyim sektöründe rekabet gücüne sahiptir. Ticaret Dengesi İndeks değerlerine göre Türkiye tekstil ve hazır giyim ihracatında net ihracatçı ülke konumundadır. Çalışma sonucunda elde edilen bulgular daha önceki çalışmalarda elde edilen sonuçları destekler niteliktedir.

Türk tekstil ve hazır giyim sektörü dinamik, gelişmeye açık ve potansiyel arz eden bir sektördür. Türkiye sahip olduğu doğal kaynaklarıyla, istihdam gücüyle ve işletme sayısıyla dünya tekstil ve hazır giyim piyasasında rekabet edebilir niteliktedir. Dünya tekstil ve hazır giyim pazarından Türkiye'nin payına düşeni alabilmesi için sektöre ilişkin sorunlarını çözüp rekabet gücünü artırması gerekmektedir. Rekabet gücünün artırılması için de üretim maliyetini minimize edecek önlemlerin alınması, kaliteli ve özgün üretim ile marka oluşumu teşvik edilmelidir. Küresel piyasada rekabet edebilmek için Türkiye’nin güçlü markalara ihtiyacı bulunmaktadır. Bununla birlikte, mevcut kayıtdışı üretim ile etkin bir şekilde mücadele edilmesi gerekmektedir. Zira kayıt dış1 ticaret rekabeti olumsuz etkilemektedir. Ayrıca, Türkiye'nin dünya tekstil ve hazır giyim pazarından aldığı payı artırmak için ihracatta pazar çeşitlendirmesine gidilmelidir. İhracatta pazar çeşitlendirmesine gidilerek rakiplerle mücadelede rekabet avantajı yakalanabilir. 


\section{KAYNAKÇA}

AKTAN, C.C., VURAL, Y.İ. (2004). Rekabet Gücü ve Rekabet Stratejileri, TİSK Yayını, Ankara.

ALTAY, O., GACANER, A. (2003). Turkey's Dynamics of Competition: A Comparative Analysis of Competitiveness of the Textile and Clothing Industry, paper presented at the VII.ERC/METU International Economy Congress, Ankara.

ALTAY TOPÇU, B., SÜMERLİ SARIGÜL, S. (2015). Comparative Advantage and the Products Mapping of Exporting Sectors in Turkey, Akademik Sosyal Araştırmalar Dergisi, 3(18), 330-348.

ALTINTAŞ, N., AKPOLAT, A.G. (2013). Tekstil Sektöründe Avrupa Birliği İle Türkiye Arasındaki Rekabet Analizi, KAÜ İ.I.B.F. Dergisi, 4(6), 33-42.

ARSLAN, K. (2008). Küresel Rekabet Baskısı Altında Tekstil ve Hazır Giyim Sektörünün Dönüşüm Stratejileri ve Yeni Yol Haritası, MÜSİAD Araştırma Raporları: 57, İstanbul.

ARUOBA, Ç. (1999). Dünya Tekstil Ekonomisi, ONGUN, M.T. (Editör), Anadolu'da Hızla Sanayileşen Kentler: Kahramanmaraş Örneği, Türkiye Ekonomi Kurumu Yayını, Ankara.

AYDOĞUŞ, İ., DİLER, H.G. (2009). Tekstil Ürünleri İhracatında Stratejik Dış Ticaret Yaklaşımı: Türkiye ve Çin Üzerine Bir Uygulama, Afyon Kocatepe Üniversitesi I.I.B.F.F. Dergisi, 11(2), 1-17.

AYNAGÖZ ÇAKMAK, Ö. (2005). Açıklanmış Karşılaştırmalı Üstünlükler ve Rekabet Gücü: Türkiye Tekstil ve Hazır Giyim Endüstrisi Üzerine Bir Uygulama, Ege Akademik Bakış Dergisi, 5(1-2), 65-76.

AZHIMETOVA, G. (2010). Current State of the Cotton and Textile Industry in Kazakhstan, Perspectives of Innovations, Economics \& Business, 5(2), 37-40.

CAN, Ö, (2009), Tekstil Kobilerinde İnovasyon, Tekstil Teknolojileri Elektronik Dergisi, $3(1), 57-63$.

COROVIC, E., JOVANOVIC, P., RISTIC, L. (2013). Current Trends on the World Textile Market and the Competitiveness of the Serbian Textile Industry, FIBRES \& TEXTILES in Eastern Europe, 21, 5 (101), 8-12.

ÇETIN, M., ECEVIT, E. (2008). İhracatın Sürükleyici Gücü Olarak Tekstil Sektörü: Kahramanmaraş İli Örneği, Celal Bayar Üniversitesi İ.I.B.F. Yönetim ve Ekonomi Dergisi, 15(2), 115-132.

ÇIVİ, E. (2001). Rekabet Gücü: Literatür Çalışması, Celal Bayar Üniversitesi İ.I.B.F. Yönetim ve Ekonomi Dergisi, 8(2), 22-38.

ÇOBAN, O., KÖK, R. (2005). Türkiye Tekstil Endüstrisi ve Rekabet Gücü: AB Ülkeleriyle Karşılaştırmalı Bir Analiz Örneği (1989-2001), Ikktisat, İşletme ve Finans Dergisi, 20(228), 68-81.

DALUM, B., LAURSEN, K., VILLUMSEN, G. (1998). Structural Change in OECD Export Specialization Patterns: De-specialization and 'Stickiness', International Review of Applied Economics, 12, 447-467.

DTÖ. (2016). International Trade Statistics，www.wto.org/statistics [Erişim: 20.11.2016] 
ERASLAN, İ.H., BAKAN, İ., HELVACIOĞLU KUYUCU, A.D. (2008). Türk Tekstil ve Hazır Giyim Sektörünün Uluslararası Rekabetçilik Düzeyinin Analizi, İstanbul Ticaret Üniversitesi Sosyal Bilimler Dergisi, 7(13), 265-300.

ERKAN, B. (2013). Türkiye'nin Tekstil ve Hazır Giyim Sektörü İhracatında Uluslararası Rekabet Gücünün Belirlenmesi, Anadolu Üniversitesi Sosyal Bilimler Dergisi, 13(1), 93-110.

ERLAT, G., ERLAT, H. (2004). Türkiye'nin Orta Doğu Ülkeleri ile Olan Ticareti, 19902002, UYGUR, E. ve CIVCIR, İ. (Editör), GAP Bölgesinde Dış Ticaret ve Tarım, Türkiye Ekonomi Kurumu Yayını, Ankara.

EROĞLU, Ö., ÖZDAMAR, G. (2006). Türk İmalat Sanayiinin Rekabet Gücü ve Beyaz Eşya Sektörü Üzerine Bir İnceleme, Akdeniz Üniversitesi İktisadi ve İdari Bilimler Fakültesi Dergisi, 6(11), 85-104.

FERTÖ, I. (2007). The Dynamics of Trade in Central and Eastern European Countries, Managing Global Transitions, 5(1), 5-23.

FUKUNISHI, T., GOTO, K., YAMAGATA, T. (2013). Aid for Trade and Value Chains in Textiles and Apparel, OECD/WTO/IDE-JETRO.

HAVRILA, I., GUNAWARDANA, P. (2003). Analysing Comparative Advantage and Competitiveness: An Application to Australia's Textile and Clothing Industries, Australian Economic Papers, 42(1), 103-117.

HINLOOPEN, J., MARREWIJK, C.V. (2001). On the Empirical Distribution of the Balassa Index, Review of World Economics, 137(1), 1-35.

HINLOOPEN, J., MARREWIJK, C.V. (2004). Dynamics of Chinese Comparative Advantage, Tinbergen Institute, Discussion Paper, No: TI 2004-034/2, Rotterdam.

ISHCHUKOVA, N., SMUTKA, L. (2013). Comparative Advantage: Products Mapping of the Russian Agricultural Exports, Agris on-line Papers in Economics and Informatics, 5(3), 13-24.

JAMES, W.E. (2004). Comparative Advantage in Thailand and Indonesia and Thailand's Free Trade Agreements: Potential Diversion of Indonesian Exports, USAID/GOI Project Report.

KAYA, Ö. (2013). Türkiye'deki Tekstil-Konfeksiyon İşletmelerinin (Kobi'lerinin) Tedarik, Üretim ve Lojistik Faaliyetlerinin Ulusal Rekabet Üzerindeki Etkileri, Yayınlanmamış Doktora Tezi, Gazi Üniversitesi Eğitim Bilimleri Enstitüsü, Ankara.

KAYA, Ö., ODUNCU, A. (2016). Türk Tekstil Sektörünün Uluslararası Rekabet Gücü Değerlendirmesi, Akademik Bakış Dergisi, 54, 418-428.

KEANE, J., Te VELDE, D.W. (2008). The Role of Textile and Clothing Industries in Growing and Development Strategies, Final Draft, Overseas Development Institute, UK.

KELLECI, S. (2009). Avrupa Birliği'ne Giriş Sürecinde Türkiye'nin Rekabet Gücü: Karşılaştırmalı Üstünlükler Modeline Göre Sektörel Bir Analiz, Yayınlanmamış Doktora Tezi, Adnan Menderes Üniversitesi Sosyal Bilimler Enstitüsü, Aydın. 
LAURSEN, K. (1998). Revealed Comparative Advantage and the Alternatives as Measures of International Specialization, Danish Research Unit for Industrial Dynamics (DRUID) Working Paper No: 98-30.

MA, A.S. (2013). Revealed Comparative Advantage Measure: ASEAN-China Trade Flows, Journal of Economics and Sustainable Development, 4(7), 136-145.

ÖZÇALIK, M., OKUR, A. (2013). Türk Tekstil ve Hazır Giyim Sektörlerinin Gümrük Birliği Sonrası AB-15 Ülkeleri Karşısındaki Rekabet Gücü, CBÜ Sosyal Bilimler Dergisi, 11(1), 205-223.

RAHMADDI, R., ICHIHASHI, M. (2012). The Changing Pattern of Export Structure and Competitiveness in Indonesia's Manufacturing Sectors: An Overview and Assessment, IPEDR, 36, 7-11.

ŞAHIN, D. (2015). Türkiye ve Çin'in Tekstil ve Hazır Giyim Sektöründe Rekabet Gücünün Analizi, Akademik Bakış Dergisi, 47, 155-171.

ŞAHIN, D. (2016a). Tekstil ve Hazır Giyim Sektöründe Rekabet Gücü: Türkiye, Çin, Hindistan ve Pakistan Örneği, Kesit Akademi Dergisi, 2(3), 71-84.

ŞAHIN, D. (2016b). An Analysis on the International Competitiveness of Textile and Clothing Industry in ASEAN-5 Countries, Uluslararası Hakemli Ekonomi Yönetimi Araştırmaları Dergisi, 8, 14-25.

TANDON, N., REDDY, E.E. (2013). A Study on Emerging Trends in Textile Industry in India, AMET International Journal of Management, 5(5), 81-88.

UN COMTRADE. (2016). https://comtrade.un.org/data/ [Erişim: 08.11.2016]

WATCHRAVESRINGKAN, K., KARPOVA, E., HODGES, N.N., COPELAND, R. (2010). The Competitive Position of Thailand's Apparel Industry: Challenges Opportunities for Globalization, Journal of Fashion Marketing and Management, 14(4), 576-597.

WIDODO, T. (2008). Shift in Comparative Advantage, Dynamic Market and Purchasing Power Parity in the East Asia, Doctoral Thesis, Graduate School of Economics Hiroshima University of Economics, Hiroshima, Japan.

YEAN, S.T. (2001). Competitiveness of Malaysian Exports, Kajian Malaysia, XVIX(1), 135.

YOU, S.; CHENG, S., YAN, H. (2009). The Impact of Textile Industry on China's Environment, International Journal of Fashion Design, Technology and Education, 2(1), 33-43.

YÜCEL, Y. (2010). Uluslararası Ticaretin Serbestleştirilmesi Sürecinde Türk Tekstil ve Hazır Giyim Sektörünün Rekabet Gücü ve Çin Tehdidi, Marmara Üniversitesi I.I.B.F. Dergisi, 29(2), 227-250. 